\title{
Ehrlichia canis morulae and DNA detection in whole blood and spleen aspiration samples
}

\author{
Detecção de mórulas e DNA de Ehrlichia canis em sangue e em aspirado de baço \\ em cães naturalmente infectados \\ Joice Lara Maia Faria ${ }^{1,3}$; Ana Sílvia Dagnone'; Thiago Demarchi Munhoz ${ }^{3}$; Carolina Franchi João; \\ Wanderson Adriano Biscola Pereira ${ }^{1}$; Rosângela Zacarias Machado ${ }^{4}$; Mirela Tinucci-Costa ${ }^{5 *}$
}

\author{
${ }^{1}$ Medicina Veterinária, Universidade de Uberaba - UNIUBE \\ ${ }^{2}$ Medicina Veterinária, Centro Universitário de Rio Preto - UNIRP \\ ${ }^{3}$ Medicina Veterinária, Programa de Pós-graduação, Faculdade de Ciências Agrárias e Veterinária - FCAV, \\ Universidade Estaudal Paulista - UNESP \\ ${ }^{4}$ Departamento de Patologia Veterinária, Faculdade de Ciências Agrárias e Veterinária - FCAV, \\ Universidade Estaudal Paulista - UNESP \\ ${ }^{5}$ Departamento de Clínica e Cirurgia Veterinária, Faculdade de Ciências Agrárias e Veterinária - FCAV, \\ Universidade Estaudal Paulista - UNESP
}

Received September 4, 2009

Accepted October 6, 2009

\begin{abstract}
The aim of this study was to compare the detection of Ehrlichia canis morulae and DNA by nPCR in whole blood and spleen aspiration. The sample included 40 dogs showing thrombocytopenia associated to clinical signs suggestive of canine ehrlichiosis. Morulae detection showed that in 35 of the dogs studied, 17 had morulae in spleen tissue, and two in buffy coat smears. E. canis DNA was detected in 29/40 blood samples. We verified that morulae detection is more efficient in cytological preparations from spleen aspiration. On the other hand, nPCR on spleen and blood samples were equally efficient for disease diagnosis.
\end{abstract}

Keywords: Ehrlichia canis, morulae, spleen, nPCR, dogs.

\section{Resumo}

O objetivo desse estudo foi comparar a pesquisa de mórulas de Ehrlichia canis e a nPCR em sangue total e em aspirado de baço. Selecionaram-se 40 cáes apresentando trombocitopenia associada a sinais e sintomas sugestivos de erliquiose canina. A pesquisa de mórula mostrou que dentre 35 amostras, 17 apresentaram mórulas nas preparaçóes do baço, e duas nos esfregaços feitos a partir da papa leucocitária. O DNA de Ehrlichia canis foi detectado em 29 de 40 amostras de baço e em 30 de 40 no sangue. No presente estudo observou-se que a pesquisa de mórula é mais eficiente nas preparaçóes citológicas obtidas da punção aspirativa do baço e que tanto a nPCR de baço quanto a de sangue foram eficientes no diagnóstico da doença.

Palavras-chave: Ehrlichia canis, mórula, baço, nPCR, cães.

\section{Introduction}

Canine ehrlichiosis is an infectious disease caused by the gram-negative bacterium Ehrlichia canis and transmitted by the brown dog tick Rhipicephalus sanguineus (LEWIS et al., 1977). The disease is reported in many countries, being more common in tropical and subtropical regions (NEER; HARRUS, 2006).

\footnotetext{
${ }^{*}$ Corresponding author: Mirela Tinucci-Costa

Departamento de Clínica e Cirurgia Veterinária,

Faculdade de Ciências Agrárias e Veterinária - FCAV,

Universidade Estaudal Paulista - UNESP, Campus de Jaboticabal, Via de acesso

Prof. Paulo Donatto Castellane s/n, CEP 14.884-900 Jaboticabal - SP, Brazil;

e-mail:mirelatc@fcav.unesp.br
}

The incubation period of canine ehrlichiosis can range from 8 to 20 days (CASTRO et al. 2004; NEER; HARRUS, 2006), followed by the acute, subclinical, and chronic phases of the disease (HARRUS et al., 1999). The acute phase lasts 2 to 4 weeks (NEER; HARRUS, 2006) and is characterized by fever, weight loss, anorexia, depression, linphadenomegaly, spleenomegaly, vasculites, and ocular and musculoescheletic signs (WANER et al., 1999; DAGNONE; MORAIS; VIDOTTO, 2001; CASTRO et al. 2004). Thrombocytopenia is the most common abnormality in naturally or experimentally infected dogs in this disease phase (WANER et al., 1995).

The subclinical phase has a duration that varies from months to years (CODNER; FARRIS-SMITH, 1986; NEER; 
HARRUS, 2006). During this phase the animal could show high anti-E. canis antibody titers (WANER et al., 1997), persistent thrombocytopenia, and leucopenia with no other clinical signs (CODNER; FARRIS-SMITH, 1986; WANER et al., 1997; HARRUS et al., 1998a). It has been suggested that during this phase the organism stays housed in the animal's spleen (HARRUS et al., 1998a, 2004). Severe pancytopenia, hemorrhagic diatesis, and organism debilitation can characterize the chronic phase (NEER; HARRUS, 2006). Although the conditions that can lead the animal to this phase are not totally clear, it has been suggested that factors such as breed, immune system deficiency, stress conditions, co-infections, virulence strain, and geographical region could have some influence (HARRUS et al., 1998a).

Diagnosis can be done by direct identification of inclusion bodies or morulae of E. canis in leucocytes from blood smears (ELIAS, 1991), or from buffy coat smears and lymphonode aspiration (MYLONAKIS et al., 2003). Detection of specific antibodies by the immunofluorescent antibody test (IFAT) and Dot-ELISA (OLIVEIRA et al., 2000; CADMAN et al., 2004; NAKAGHI et al., 2008), and by molecular techniques such as nPCR (WEN et al., 1997; NAKAGHI et al., 2008) are also used as diagnostic methods.

This study sought to investigate whether the presence of morulae in splenic aspirate smears could be used as diagnosis of canine ehrlichiosis, since there is evidence that the spleen could shelter the parasite and participate in the pathogenesis of this disease. In addition, we also investigated the presence of parasite DNA in blood samples and spleen tissue of dogs with clinical suspicion of naturally occurring canine ehrlichiosis.

\section{Material and Methods}

\section{Animals}

Forty dogs suspected of being infected with $E$. canis cared for at the Veterinary Teaching Hospital of Universidade Estadual Paulista (UNESP) in Jaboticabal, SP, Brazil from April 2004 to May 2005 were used in this study. The inclusion criteria of these dogs were the presence of thrombocytopenia with one or more clinical signs of the disease: anorexia, apathy, splenomegaly, lymphadenopathy, uveitis, hemorrhagic diatesis, or tick infestation. From each dog we collected $10 \mathrm{~mL}$ of blood, one aliquot with ethylenediaminetetraacetic acid (EDTA) to be used for the buffy coat smear and nPCR. The other aliquot without EDTA was used to obtain serum samples used to detect anti-Babesia canis antibodies by IFAT and anti-E. canis antibodies by Dot-ELISA. Spleen fine needle aspiration samples were used in morulae search and in DNA extraction for nPCR. All the procedures were performed with the dog owner's permission, and the rules of Comitê de Ética, Bioética e Bem Estar Animal were followed as instructed by the UNESP.

\section{Morulae detection}

Morulae detection was performed using the buffy coat blood smears and the splenic aspirated samples.
The fine needle aspiration was performed in 35 among 40 samples. The dogs were restrained by hand in dorsal decubitus and ultrasound-guided fine needle aspiration biopsies were performed, with a $2.0 \mathrm{~mL}$ sample collected with EDTA. Then sample smears were done and let dry at room temperature.

The buffy coat was obtained from $1.5 \mathrm{~mL}$ of EDTA whole blood sample transferred to a sterile microtube and centrifuged at $2,500 \mathrm{~g}$ for 10 minutes. The buffy coat was collected to make the smears in the same way as described for the spleen samples. Both the smears (spleen and buffy coat) were methanol fixed for 3 minutes and Giemsa stained. The slides were visualized by optic microscopic at $1,000 \times$.

\section{DNA extraction and $n P C R$}

DNA extraction from blood and spleen samples was performed using QIAmp DNA Blood Mini kit (Qiagen ${ }^{\circ}$ ) according to manufacturer's instructions. The amplification was performed in two steps in a thermocycler (MJ-Reasearch-PTC-200) as previously described (HARRUS et al., 1998a; MURPHY et al., 1998; NAKAGHI et al., 2008). The first round used $5.0 \mu \mathrm{L}$ of template DNA in $5.0 \mu \mathrm{L}$ PCR buffer $10 \times(100 \mathrm{mM}$ Tris-HCl, $\mathrm{pH} 9.0,500 \mathrm{mM}$ $\mathrm{KCl}), 0.2 \mathrm{mM}$ each dNTP, $2.5 \mathrm{mM} \mathrm{MgCl}_{2}$ (Invitrogen $^{\circ}$ ), 1 pmol each primer ECC (5'- GAACGAACGCTGGCGGCAAGC -3') and ECB (5'- CGTATTACCGCGGCTGCTGGCA -3'), $1.25 \mathrm{U}$ of Taq DNA polymerase (Invitrogen ${ }^{\circ}$ ) and water to complete $50 \mu \mathrm{L}$. The PCR cycles consisted of 3 minutes at $94^{\circ} \mathrm{C}$, 30 cycles of $94{ }^{\circ} \mathrm{C}$ for 45 seconds, $65^{\circ} \mathrm{C}$ for 2 minutes, $72{ }^{\circ} \mathrm{C}$ for 2 minutes, and a final extension at $72^{\circ} \mathrm{C}$ for 5 minutes. The $\mathrm{nPCR}$ assay was performed using the same reaction conditions as the first amplification, but species-specific primers ECAN (5'- CAATTATTTATAGCCTCTGGCTATAGGA -3') and HE3 (5' - TATAGGTACCGTCATTATCTTCCCTAT -3'), and $1.0 \mu \mathrm{L}$ from the initial PCR was used as template. The PCR consisted of 3 cycles of 1 minutes at $94,55^{\circ} \mathrm{C}$ for 2 minutes, and $72{ }^{\circ} \mathrm{C}$ for 1 minute and 30 seconds, followed by 37 cycles of 1 minute at $92,55^{\circ} \mathrm{C}$ for 2 minutes, and $72{ }^{\circ} \mathrm{C}$ for 1 minute and 30 seconds, and a final extension at $72{ }^{\circ} \mathrm{C}$ for 5 minutes. The PCR products were visualized on a $1.5 \%$ agarose gel stained with ethidium bromide and UV light. The positive sample used as a control was obtained from a dog that was experimentally infected with E. canis Jaboticabal strain, and ultrapure water was used as negative control. The amplified products were measured using a $100 \mathrm{bp}$ DNA ladder (Invitrogen $\left.{ }^{\circ}\right)$. DNA extraction and master-mix preparation were processed in different laboratories to avoid contamination.

\section{Anti-E. canis and anti-B. canis antibodies detection by serology}

In order to evaluated the presence of anti-E. canis antibodies we used the Immunocomb kit $^{\bullet}$ (Biogal, Israel) following the manufacturer's instructions. To detect anti-B. canis antibodies, a IFAT protocol previously described by Furuta et al. (2009) was used. Briefly, $2.0 \mu \mathrm{L}$ of serum samples were diluted $(1: 40,1: 80$, $1: 160,1: 320,1: 640,1: 1280)$ and were dropped in the marked 
areas with $B$. canis antigen sensibilized, and then incubated for 45 minutes in $32^{\circ} \mathrm{C}$ in a humid chamber. Then followed a series of washes and a final drying step by addition of the conjugated (Sigma ${ }^{\oplus}$ - F7884) diluted in 1:80 according to manufacturer's instructions. All the slides were viewed in an optic microscope with fluorescent light (Olympus BX60), and the serum samples were considered positive when they reacted in dilutions greater than $1: 40$

\section{Statistical analyses}

The results were analyzed using the chi-square test with 5\% significance level in an SAS software program (Statistical Analysis System, 2006).

\section{Results}

\section{Morulae detection}

Among 35 samples collected from dogs with clinical signs of ehrlichiosis, 17 (48.6\%) showed intracytoplasmatic morulae in spleen aspiration (Figure 1) and two (5.7\%) showed in buffy coat.

\section{2. $n P C R$}

The nPCR results showed that from all 40 samples analyzed, the $E$. canis DNA was isolated in $29(72.5 \%)$ spleen samples and in $30(75 \%)$ whole blood samples. The ehrlichial DNA was not isolated in $11(27.5 \%)$ spleen samples and in $10(25 \%)$ whole blood samples. These results can be seen in Table 1 . The product of 398 base pairs corresponding to the amplified E. canis DNA is shown in Figure 2 ( $\mathrm{a}$ and $\mathrm{b}$ ). The results do not show a statistical difference $(p>0.05)$ in ehrlichial DNA detection in spleen aspirates and whole blood by the $\mathrm{nPCR}$ reaction, showing that both techniques are effective in the diagnosis of naturally occurring canine ehrlichiosis.

\section{Presence of anti-E. canis and anti-B.canis antibodies}

Amid the 40 samples evaluated, 33 (82.5\%) presented antibody titers for E. canis and 28 (70\%) for B. canis. Amid the 33 samples with $E$. canis titers, in two of them we could not isolate the bacteria DNA in blood and spleen samples and no morulae were found, except in one where morulae were found in spleen tissue and leukocyte smear.

\section{Positivity frequency between diagnostic tests}

In 30 positive nPCR whole blood samples, 28 were also spleen sample nPCR positive, 26 in Dot-ELISA, and 21 in anti- $B$. canis IFAT test. Fifteen samples showed morulae in spleen cytology, and one of these was also positive in buffy coat smear. Among 29 spleen nPCR positive animals, 28 were also whole blood nPCR positive, 22 in Dot-ELISA, and 22 in anti-B. canis IFAT.
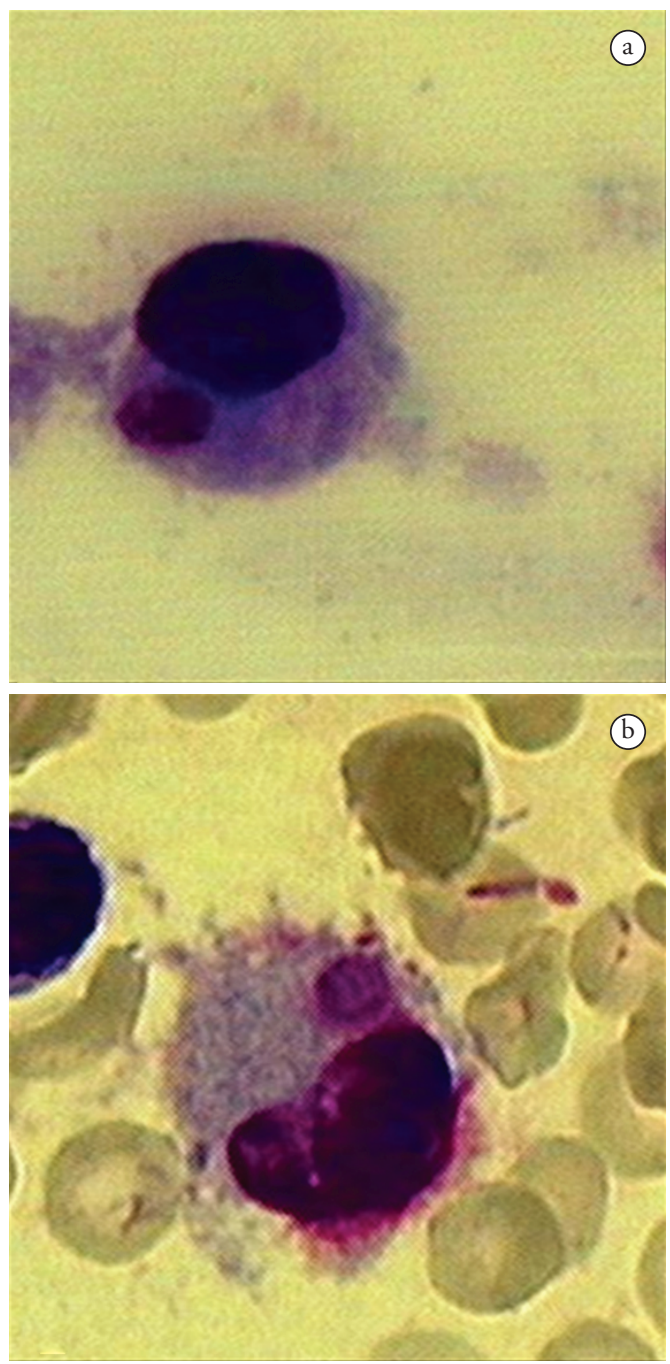

Figure 1. Photomicrography of cytological smears of spleen aspiration slowing a morula in the mononuclear cells in a and b. 100x. Giemsa stained.

Table 1. Dogs naturally infected and positive or negative for E. canis DNA.

\begin{tabular}{lccc}
\hline & $\begin{array}{c}\text { Positive } \\
\text { animals }\end{array}$ & $\begin{array}{c}\text { Negative } \\
\text { animals }\end{array}$ & $\begin{array}{c}\text { Total of } \\
\text { animals }\end{array}$ \\
\hline nPCR (blood) & 30 & 10 & 40 \\
nPCR (spleen) & 29 & 11 & 40 \\
\hline
\end{tabular}

Fourteen had morulae in spleen cytology and one in buffy coat smear. These results can be seen in Table 2. From the 40 evaluated animals, two were positive only in Dot-ELISA, one in blood nPCR, one in IFAT, and none were positive only in spleen nPCR or morulae search.

Among 17 samples in which morulae was detected in spleen aspiration, 15 were also nPCR positive in blood samples, 14 were nPCR positive in spleen samples and in Dot-ELISA, and 10 in anti-B. canis IFAT. 

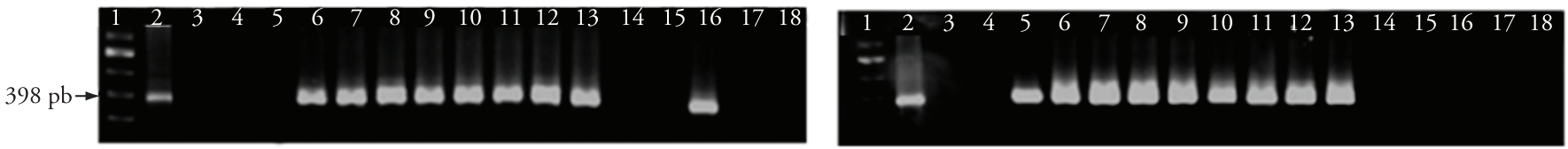

Figure 2. Amplified products by nPCR to detect E. canis DNA in spleen aspirates a) and whole blood b) samples from dogs with clinical suspicion of ehrlichiosis. Lane 1 molecular size ladder (100 pb), lane 2 positive control, lane 3 negative control (ultrapure water), lanes 4 to 18 dog samples.

Table 2. Positive animals in molecular, serological, and parasitological diagnostic tests in dogs with naturally occurring ehrlichiosis.

\begin{tabular}{clc}
\hline PCR & & Positive animals \\
\hline & nPCR b + nPCR s & $28 / 30$ \\
nPCRb (blood) & nPCR b + Dot-ELISA & $26 / 30$ \\
$(\mathrm{n}=30)$ & nPCR b + IFAT & $21 / 30$ \\
& nPCR b + Morulae & $15 / 30$ \\
\hline & nPCR $s+$ nPCR b & $28 / 29$ \\
nPCRs (spleen) & nPCR $s+$ Dot-ELISA & $27 / 29$ \\
$(\mathrm{n}=29)$ & nPCR $s+$ IFAT & $22 / 29$ \\
& nPCR s + Morulae & $14 / 29$ \\
\hline
\end{tabular}

\section{Discussion}

The results found in this study have shown that morulae search in spleen aspirates is more efficient for the parasite detection than the search in buffy coat smear. Other studies have also observed a low frequency of morulae in buffy coat smears and they have attributed this feature to the low parasitemia that occurs under natural infection (ELIAS, 1991; HARRUS; BARK; WANER, 1997; FRANK; BREITSCHWERDT, 1999; OLIVEIRA et al., 2000). The low parasitemia could be due to the bacteria remaining lodged in the spleen longer than in the blood, justifying the higher number of morulae in this organ.

The high number of morulae-positive samples in spleen aspiration shown in this study is in disagreement with what Harrus et al. (1998a) previously reported. One possible explanation could be associated to the time of sample collection. While Harrus et al. (1998a) evaluated dogs during the experimental and sub-clinical phase of the disease, in our study we studied naturally infected animals that could be presenting any of the three possible phases of the disease. Even though some animals in our study could also be presenting the sub-clinical phase of the disease, the knowledge we currently have on how the bacteria behaves in naturally infected animals and on its cycle in the host is still poor.

Some researchers believe that the spleen could be the shelter for ehrlichial organisms for periods longer than the bacterial time in the blood (FOLEY et al., 1999; HARRUS et al., 2004). This feature could justify the higher number of morulae detected in the spleen in this experiment. However the results of this search didn't show better results in the detection of ehrlichial DNA in spleen than in blood and they disagree with the results of Harrus et al. (1998a). These researchers showed superiority in the ehrlichial DNA detection extracted from spleen of dogs in the subclinical phase of the disease. In another study, Harrus et al. (2004) showed that the early detection of the disease after infected blood inoculation in dogs as equally positive in samples of spleen and of blood. In later evaluations the spleen samples showed superiority over the blood samples in these same dogs after sixteen days of doxicicline therapy. In this study, the detection of E. canis DNA in spleen tissue and in blood samples was equally efficient, even in dogs that presented morulae in the splenic aspirate but not in the buffy coat smears. Nevertheless, in some of the dogs where E. canis DNA was isolated in spleen tissue and blood samples, no morulae were found. Further studies are needed to explain this controversy. The exact mechanism of E. canis and some rickettsiae to stay sheltered in the host is not completely understood (FOLEY et al., 1999). Some studies suggest that the spleen produces inflammatory mediators and other splenic substances that could collaborate in the bacterial persistence in the host and therefore they could act in the disease pathogenesis (HARRUS et al., 1998b). In addition, it was demonstrated that splenectomized dogs experimentally infected with $E$. canis suffer from a milder form of the disease, when compared to non-splenectomized dogs (HARRUS et al., 1998b). On the other hard, splenectomized human beings had a more severe type of ehrlichiosis than nonsplenectomized patients (RABINSTEIN et al., 2000), probably because there is a reduction in the antigen's clearance, a decrease in responses against new antigens, and a decrease in phagocytosis and in other protective responses (DAVIDSON; WALL, 2001). These different spleen functions against pathogenic agents could be due to multiple differences in the structure and function of the organ in the species, as suggested by Bowdler (2002).

In one dog, E. canis DNA was found in spleen tissue but not in blood samples. In two others, the opposite was true: DNA was isolated from blood but not from spleen samples. The dog with spleen nPCR positive was pancitopenic and had titers of antibodies anti-E. canis of 1:1280 and anti-B. canis of 1:160. The morulae search of this animal was not done. The other blood-positive and spleen-negative dogs didn't have anti-E. canis and anti-B. canis antibodies, were anemic and thrombocytopenic, and had leukocytosis (data not shown). One of them had E. canis morulae in spleen cytology. These anomalies may suggest that the $\mathrm{nPCR}$ could have false negatives results caused by low parasitemia, as reported by Harrus et al. (2004). Although the nPCR is a highly sensitive and specific assay, it should not be the only diagnostic test (WEN et al., 1997). The low frequency of positive dogs in only one of the tests reinforces the idea that the definitive diagnosis of canine ehrlichiosis should be one by more than one test, combined with clinical signs and symptoms presented by the animal. 
The present study showed that among the assays for the diagnosis of naturally occurring canine ehrlichiosis, the search for morulae in splenic aspirates is more efficient than in buffy coat smears when it is intended to provide parasitological diagnosis of canine ehrlichiosis. It is important to note that the search for morulae in the spleen tissue is a low-cost assay with easy execution, and which can be safely applied by the clinician to the diagnosis of canine ehrlichiosis. Additionally the spleen nPCR is as efficient as the blood nPCR in the molecular diagnosis of naturally occurring canine ehrlichiosis.

\section{Acknowledgements}

We would like to thank the Fundação de Amparo à Pesquisa do Estado de São Paulo (FAPESP 2004/04383-2) and Coordenação de Aperfeiçoamento de Pessoal de Nível Superior (CAPES) for financial support.

\section{References}

BOWDLER, A. J. The Clinical significance of the spleen. In: BOWDLER, A. J. The Complete Spleen: structure, function, and clinical disorders. Second Edition, New Jersey: Humana Press Inc, 2002. p 139-156.

CADMAN, H. F. et al. Comparison of the dot-blot enzyme linked immunoassay with immunofluorescence for detecting antibodies to Ehrlichia canis. Veterinary Record, v. 135, n. 15, p. 362, 2004.

CASTRO, M. B. et al. Experimental acute canine monocytic ehrlichiosis: clinicopathologic and immunopathological findings. Veterinary Parasitology, v. 119, n. 1, p. 73-86, 2004.

CODNER, E. C.; FARRIS-SMITH, L. L. Characterization of the subclinical phase of ehrlichiosis in dogs. Journal American Veterinary Medical Association, v. 189, n. 1, p. 47-50, 1986.

DAGNONE, A. S.; MORAIS, H. S. A.; VIDOTTO, O. Erliquiose nos animais e no homem. Semina: Ciências Agrárias, v. 22, n. 2, p. 115-248, 2001.

DAVIDSON, R. N.; WALL, R. A. Prevention and management of infections in patients without a spleen. Clinical Microbiology Infection, v. 7, n. 12, p. 657-660, 2001.

ELIAS, E. Diagnosis of ehrlichiosis from the presence of inclusion bodies or morulae of E. canis. Journal of Small Animal Practice, v. 33, n. 11, p. 540-543, 1991.

FOLEY, J. E. et al. A simian model of human granulocytic ehrlichiosis. American Journal of Tropical Medicine and Hygiene, v. 60, n. 6, p. $987-993,1999$.

FURUTA, P. I. et al. Comparison between a soluble antigen-based ELISA and IFAT in detecting antibodies against Babesia canis in dogs. Revista Brasileira de Parasitologia Veterinária, v. 18, n. 3, p. 41-45, 2009.

FRANK, J. R.; BREITSCHWERDT, E. B. A retrospective study of ehrlichiosis in 62 dogs from North Carolina and Virginia. Journal of Veterinary Internal Medicine, v. 13, n. 3, p. 194-201, 1999.
HARRUS, S.; BARK, H.; WANER, T. Canine monocytic ehrlichiosis: an update. Compendium on Continuing Education for the Practicing Veterinarian, v. 19, n. 4, p. 431-447, 1997.

HARRUS, S. et al. Amplification of ehrlichial DNA from dogs 34 months after infection with Ehrlichia canis. Journal of Clinical Microbiology, v. 36, n. 1, p. 73-76, 1998a.

HARRUS, S. et al. Investigation of splenic functions in canine monocytic ehrlichiosis. Veterinary Immunology Immunopathology, v. 62, n. 1, p. $15-27,1998 b$.

HARRUS, S. et al. Recent advances in determining the pathogenesis of canine monocytic ehrlichiosis. Journal of Clinical Microbiology, v. 37 , n. 9, p. 2745-2749, 1999.

HARRUS, S. et al. Comparison of simultaneous splenic sample PCR with blood sample PCR for diagnosis and treatment of experimental Ehrlichia canis infection. Antimicrobial Agents and Chemotherapy, v. 48, n. 11, p. 4488-4490, 2004.

LEWIS, G. E. et al. The brown dog tick Rhipicephalus sanguineus and the dog as experimental hosts of Ehrlichia canis. American Journal Veterinary Research, v. 38, n. 12, p. 1953-1955, 1977.

MYLONAKIS, M. E. et al. Evaluation of cytology in the diagnosis of acute canine monocytic ehrlichiosis (Ehrlichia canis): a comparison between five methods. Veterinary Microbiology, v. 91, n. 2-3, p. 197-204, 2003.

MURPHY, G. L. et al. A molecular and serologic survey of Ehrlichia canis, E. chaffeensis, and E. ewingii in dogs and ticks from Oklahoma. Veterinary Parasitology, v. 79, n. 4, p. 325-329, 1998.

NAKAGHI, A. C. H. et al. Canine ehrlichiosis: clinical, hematological, serological and molecular aspects. Ciência Rural, v. 38, n. 3, p. 766-770, 2008.

NEER, M. T.; HARRUS, S. Ehrlichiosis, Neorickettsiosis, Anaplasmosis and Wolbachia infection. In: GREENE, C. E. Infectious diseases of the dog and cat. Philadelphia: Elsevier, 2006. p. 203-216.

OLIVEIRA, D. et al. Anti-Ehrlichia canis antibodies detection by "Dot-ELISA" in naturally infected dogs. Revista Brasileira de Parasitologia Veterinária, v. 9, n. 1, p. 1-5, 2000.

RABINSTEIN, A. et al. Recurrent and prolonged fever in asplenic patients with human granulocytic ehrlichiosis. QJ Medicine, v. 93, n. 3, p. 198-201, 2000.

WANER, T. et al. Demonstration of serum antiplatelet antibodies in experimental acute canine ehrlichiosis. Veterinary Immunology Immmunopathology, v. 48, n. 1-2, p. 177-182, 1995.

WANER, T. et al. Characterization of subclinical phase of canine ehrlichiosis in experimentally infected beagles dogs. Veterinary Parasitology, v. 69, n. 3-4, p. 307-317, 1997.

WANER, T. et al. Canine Monocytic Ehrlichiosis - an overview. Israel Journal of Veterinary Medicine, v. 54, n. 4, p. 103-107, 1999.

WEN, B. et al. Comparison of nested PCR with Immunofluorescent antibody Assay for detection of Ehrlichia canis infection in dogs treated with doxycycline. Journal of Clinical Microbiology, v. 35, n. 7, p. 1852-1855, 1997. 